\title{
Displacement of Substitution in The Poetry of Yousuf III the King of Granada (D.820 AH)
}

\author{
Haneen Khalid Salman*, Ali Mohammad Abed \\ Department of Arabic Language, College of Arts, Al -Anbar University, Iraq \\ * hkeem.khalid@uoanbar.edu.iq
}

\begin{abstract}
:
Displacement is one of stylistic terms and concepts, which appeared with modern poetry, especially in poetry, because poetic Language is popular with scholars and thinkers, and ancient Arab studies have paid attention to this phenomenon, but it has been expressed in other terms, such as counting, turning, violating, and paradoxical, poetic necessity and other terms, (some may think that displacement affects only expressions and structures but rather transcends them to images, ideas, meanings, vocalization, and even at the level of Letters), it is a departure from the usual and usual to formulate new meanings on other meanings that fit the poetic text, which is Also an Aesthetic addition, through which the creator transmits his emotional experience to the recipient end works to influence him, because the displacement from his departure from the ordinary achieves aesthetic and expressive value.
\end{abstract}

Keywords: $\quad$ Counting; Turning; Violating; Paradoxical; Poetic Necessity. Crossref doi https://doi.org/10.51345/.v32i1.221.g192 


\section{الانزياح الاستبدالي في شعر يوسف الثالث ملك غرناطة (ت 20 هـ) \\ حنين خالد سلمان"، أ.م.د. علي محمد عبد \\ قسم اللغة العربية، كلية الآداب، جامعة الأنبار، العراق \\ * hkeem.khalid@uoanbar.edu.iq}

\section{ملخص البـحث}

يعد الانزياح من المصطلحات الاسلوبية ومفاهيمها، التي ظهرت مع الشعرية الحديثة، في الشعر خاصة، وذلك لأن اللغة الشعرية تلقى اقبالاً من قبل الدارسين والمفكرين، وقد اهتمت الدراسات العربية القديمة بهذه الظاهرة ولكنها عبرت عنها بمصطلحات اخرى، كالعدول، و الألتفات، والانتهاك، والمفارقة، والضرورة الشعرية وغيرها من المصطلحات، (وقد يظن البعض ان الانزياح يمس التعابير والتراكيب فقط بل انه يتعداها الى الصور، والافكار، والمعاني، والالفاظ، وحتى على مستوى الحروف)، فهو خروج عن المألوف والمعتاد لصياغة معاني جديدة على معاني اخرى تناسب النص الشعري، فضلا عن كونه اضافة جمالية ينقل المبدع من خلاله تجربته الشعورية للمتلقي ويعمل على التأثير فيه، لأن الانزياح بخروجي عندي عن المألوف يجقت قيمة جمالية وتعبيرية.

الكلمات المفتاحية: العدول، الالتفات، الانتهاك، المفارقة، الضرورة الشعرية. Crossref doi https://doi.org/10.51345/.v32i1.221.g192 
المقلدمة :

يعد الانزياح الاستبدالي من اهم مرتكزات الانزياح التي خصها البلاغيون و اللسانيون وعلماء الاسلوب بقدر كبير من الاهتحام نظراً لكثرة التعابير المجازية. والحديث عن الانزياح والدلالة يحتم علينا الاشارة المى ان اللغة حرصت على ان يكون لكل دال مدلول واحد ولكل مدلول دال واحد، حيث تنزاح الدوال عن مدلولاتها فتختفي نتيجة الدلالات المألوفة للألفاظ ،لتحل محلها دلالات اخرى معهودة يسعى اليها المتكلم (1). يقوم الانزياح الدلالي على استبدال المعنى (الحقيقي) او السطحي للفظ بالمعنى (المجازي) الايحائي، وهذا ليس لتغير في المعنى، إنها تغيير في الشكل او نمط المعنى، وانتقال من المعنى المفهوم الى المعنى الانتقالي .وقد تبؤت المصطلحات البلاغية واللغوية مكانة واسعة لدى العلماء، وكان من بينها التشبيه، والاستعارة، والكناية، والثنائيات الضدية، وغيرها من الانحاط الاخرى، وقد اخذ كل مفهوم من هذه المفاهيم المكان الأوسع والخط الأوفر عند النقاد فلا نكاد نعثر على دراسة الا وقد اخذت هذه المفاهيم حصة فيها، و الذي يهمنا من هذا الامر هو ما يحصل عن طريق هذه المصطلحات من جماليات الانزياح، فالانزياح الذي يتولد من جراء استعال الشعراء لهذه المفاهيم لا يكون - بالتأكيد - بالقوة والدرجة والرقي والتأثير نفسها في المتلقي فيها تحتلف لو حصل عن طريق استعال مصطلحات اخر، فدرجة الانزياح تختلف عند حصوله في مصطلحات المفارقة و التناص عن مصطلحات التشبيه والاستعارة والكناية والمجاز وغيرها، وتمثل الاستعارة عمادة هذا النوع من الانزياح وتعني هنا الاستعارة التي ترتكز على كلمة واحدة مفردة، نجد ذلك في بيت فاليري الذي اوردة جان كوهين، (هذا السطح الهادئ الذي تمشي فيه الحمائم)(2). فقد حمل هذا البيت الشعري معاني ضمنية، غير المعنى السطحي الذي يفهمه القارئ من اول مرة، فكلمة السطح تعني البحر، وكلمة الحمائم تعني السفن، والسياق هو الذي يوضح انزياحا لغويا ويمكن ان تدعوه البلاغة (صورة بلاغية) تشمل كل من الاستعارة والمجاز المرسل، والتشبيه(3). وهنا نذكر قول (كولردج) الذي عرف به الشعر (انه افضل الألفاظ في افضل الاوضاع)(4). فاذا كان الشعراء لا يستطيعون ان يدركوا 
الالفاظ الحقيقية المطلقة فإنهم بفضل النظام الاستعاري يشيعون في نفس القارئ الحنين الى النظام والتناسق وهو ما عبر عنه ارسطو بـ(جوهرية الاستعارة)(5). لقد حظي الانزياح الاستبدالي بمكانة عالية واهتحام كبير من دارسي الأسلوب فـ(جان كوهين) درس هذا الباب سماه (المنافرة) التي تعد أنزياحات ضعيفة نسبياً، ان مصطلح المنافرة يشكل النقيض لمصطلح الملائمة التي يتم من خلالها إسناد خواص مادية الى ذوات روحية او العكس (6). و اذا انتقلنا الى العصر الحديث، نجد ابرز من اهتم بالاستعارة الناقد ريتشارد في كتابه (فلسفة البلاغة) فقد رد على كل الآراء التي قيلت بحق الاستعارة، منهم من عدها تلاعبا (بالألفاظ واعتبرت جمالا وزخرفا او قوة إضافية للغة لا على انها الشكل المكون والاساس لها)(7)، يقول كوهين في المعنى نفسه الذي قاله به ريتشارد بحق الاستعارة: (كان البلاغيون يعرفون الاستعارة البعيدة، وقد كانوا منسجمين مع الجمالية السائدة في عملهم)(8). ان هذه الانزياحات التي تحدثها الفنون البلاغية كالتشبيه، والاستعارة، والكناية، والثنائيات الضدية ... وغيرها، كانت من اهم الوسائل التي كان ها الاثر الكبير في تميز النصوص الشعرية من النصوص الثرية(9). اي ان جوهر الاسلوب هوما يحدث لدى المتلقي من خيبة الانتظار او التذبذب او الصدمة(10). وسأتناول في هذا البحث الانزياحات الاستبدالية في شعر يوسف الثالث التي تحدثها الفنون البلاغي، كالاستعارة، والتشبيه، و الكناية، و الثنائيات الضدية .

\section{1 - 1 - 1 الاستعارة}

تعد الاستعارة مظهراً من مظاهر الانزياح، إذ انها من ادق اساليب البيان تعبيراً، واكثرها تأثيراً وأجملها تصويراً، واكملها تأدية للمعنى، تعمل على مفاجأة السامع ونقله من التفكير في المعنى المعجمي المألوف الى البحث فيا خلف المعنى الموصول الى الهدف المطلوب، وهي من اهم تجليات الصورة الفنية، التي تعمل على اضمار حقيقة المعنى، وايهام القارئ (المتلقي) بدلالات وايحاءات غير التي اظهرتها. 
فالاستعارة هي (اختيار معجمي تقترن بمقتضاه كلمتان في مركب لفظي اقتراناً دلالياً ينطوي على تعارض

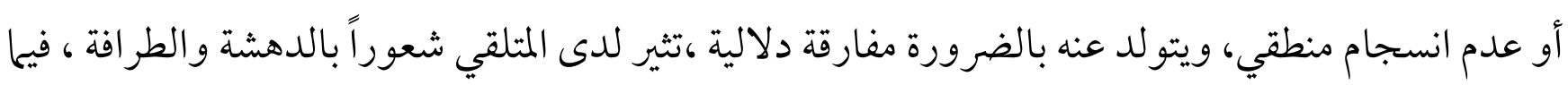

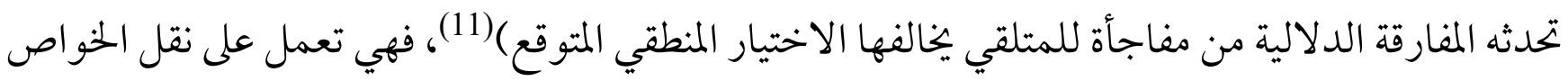

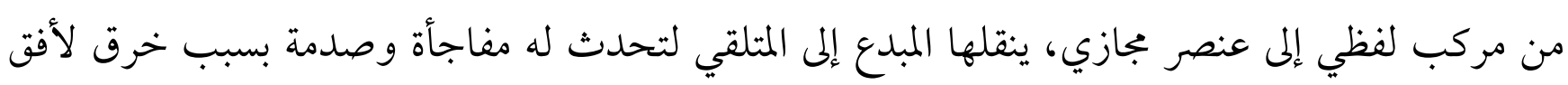

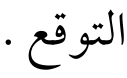
قسم البلاغيون الاستعارة الى قسمين: تصريمية ومكنية، فالاستعارة التصريجية تقوم على حذف المشبه وهو اللفظ والذي نقل من المعنى الاصلي الى الفرعي، اما الاستعارة المكنية تقوم على حذف المثبه به وهو معنى

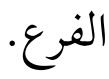
لقد حظيت الأستعارة باهتحامٍ كبيرٍ من النقد الغربي منذ أرسطو وحتى أواخر النقاد، فقد اكتسبت الأستعارة لقب يسمى منذ القديم ب(ملكة الصورة البيانية)(12). ومن النقاد الغربين الذين اولعوا بالحديث المستفيض عن موضوع الاستعارة (جان كوهين) فهي عنده (تشير

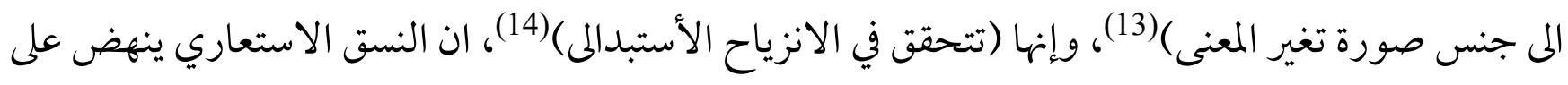
خرق المألوف في العلاقات اللغوية، فتعمل على استثارة القارئ وتحفيز ذهنه، ليتجاوز المعنى السطحي الى لى المعنى الايحائي العميق والتي لا يتمكن القارئ من الوصول اليها الاعبر قراءة المتتجة(15). ومن تبنى - مفهوم الاستعارة - من النقاد الغربين (جاكبسون)، إذ عمل على توضيح قيمتها الشكلية، فقد عد الاستعارة (معياراً

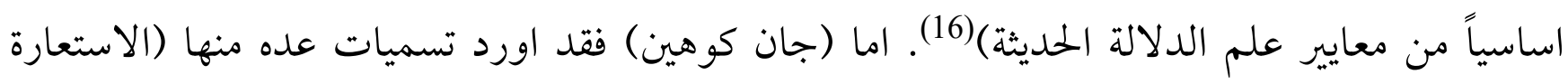
التفسيرية والاستعارة الوجدانية والاستعارة التغريبة والبعيدة ...) وعند غيرة وردت الاستعارة العنادية والمرشحة والمجردة) (17). و الى جانب ذلك فإن ما يمكن ان تحمله الاستعارة بأنو اعها قد يلعب الغموض دوراً هاما في الأبداع الفني الذي يكسب النصوص جمالا فريداً، بأخفاء المعنى وهوما يسهم في غياب الدلالة

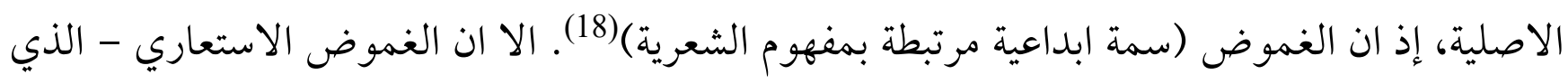

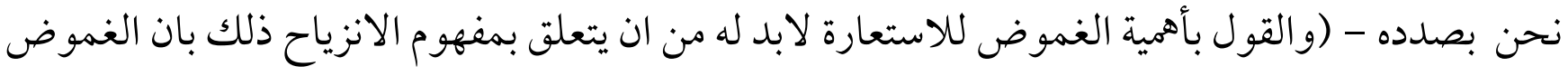


ينتج في الغالب من انشاء الشاعر علاقات جديدة بين الاشياء انشاءً لم يفطن إليه احد من قبل، ومن شان الغموض يحدث في المتلقي يؤدي الامر دهشة وغرابة ومفاجأة امام النص...)(19). وهكذا فان مسؤولية الكشف عن الابداع في النصوص تلقى على عاتق شخصين، اوها: المبدع وهو الشاعر، وثانيها: المتلقي فالمبدع (يقوم على علاقات جديدة بين الاشياء، فيعرضها عن طريق الاستعارة عرضا فيه غير قليل من الغرابة والغموض)(20)، اما الشخص الثاني: (المتلقي) حينما يفطن لما يكشف عنه المبدع ويبني عليه تصوره(21). وقد حفل شعر يوسف الثالث بالانزياحات الاستعارية الكثيرة، ومن ذلك قوله (22):

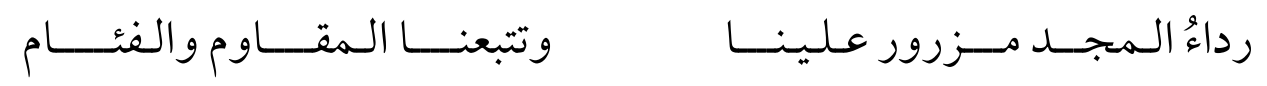

ففي هذه العبارة (رداء المجد) استعارة مكنية فقد شبه الشاعر المجد بـ(الانسان) وترك لازمه من لوازمه وهو (رداء)، حيث انه اخرج (رداء) من دائرته الحسية ونقله المى دائرة المعنوية، فقد انبثقت الرؤية الجمالية للشاعر في هذه العبارة عن معناها الحقيقي، فالمجد ليس رداء، وإنها (الانسان) هو الذي يرتدي الثياب، وبالتالي فإن هذه الاسلوب الاستعاري هو الأقدر على تجسيد الافكار والمعاني التي كانت وسيلته لنقل الصورة الى السامع، فالانزياح تجاوز حدود الواقع المألوف عند الشاعر من خلال اعطاء الصفات المعنوية صفات انسانية لا يمكن

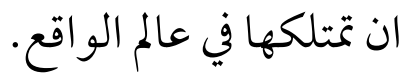
ومن ذلك قوله أيضاً(23): (23)

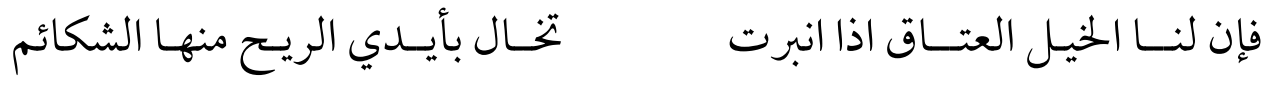

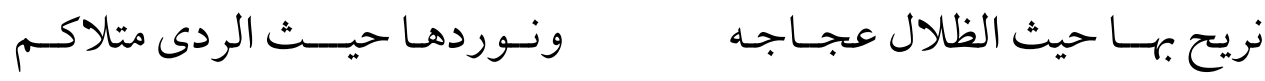

رسم الشاعر صورة معبره عن طريق الاستعارة في قوله (بأيدي الريح) وقد انزاح بالكلام من الكلام المألوف الى الكلام غير المألوف، فنرى ان الشاعر يشبه الريح (بالانسان) لكنه حذف المشبه به وابقى لازمه من لوازمه (اليد)، لذا فقد استعمل الشاعر الاستعارة المكنية خير استعمال ووظفها خير توظيف لخدمه المعنى، إذ استطاع ان يشد المتكلم ويلفت انتباهه لغرض تأويل المعنى والوصول الم معنى مناسب. اما في البيت الثاني نجد ان الشاعر يلجأ المى توظيف الانزياح الاستبدالي المتمثل في عقد المشابهة بين (الردى والانسان)، فيصور (الردى) 
بالانسان القوي، يلاكم إنسانا اخر، حذف المشبه به (الانسان) وصرح بالمشبه وهو (الردى) على سبيل

$$
\begin{aligned}
& \text { الاستعارة المكنية. ومن الامثلة الاخرى من قوله (24): } \\
& \text { والروض مبتسم الاسر ضـاحك كزمـان وصل بعد طـول عتــاب }
\end{aligned}
$$

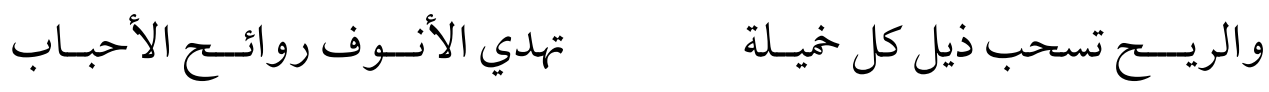

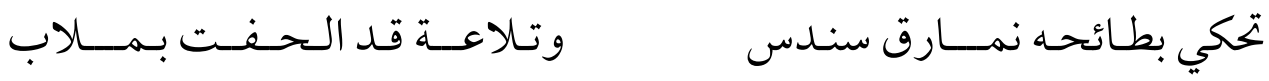

ان الانزياح الذي جسدته الانساق الاستعارية من خلال فاعلية (الفعل) عبر اسناد الالفاظ الغريبة لغير صفاتها، فالنص يستمد بنية عميقة من خلال معطيات الاستعارة، فكان التشخيص (الروض مبتسم ضاحك)، (تحكي البطائح)، (الريح تسحب وتهدي) ولكون بعض الافعال جاءت بصيغه اسم الفاعل فلها دلاله الفعل، وقد اسقط مدركا من مدركات حاسة البصر (الروض) على مدرك سمعي (مبتسم، ضاحك) فنتج عن ذلك الاسقاط سمه تواصلية اقترن فيها السمعي بالبصري، اذ يتفي وجود (روض مبتسم الاسرة

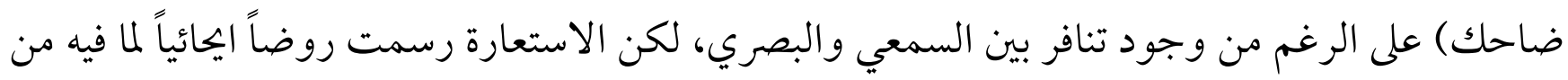
ازهار متفتحة وخضرة يانعة تسر الانفس اتساقا مع المدلول الاول (مبتسم الاسرة ضاحك) الى المعاني الثواني الذي تنتجه الاستعارة التشخيصية، وتتراسل (تحكي) السمعية مع (بطائحه نمارق سندس) البصرية كما ان تراسل المرئيات ادى الى خلق طاقة شعرية مطابقة في انتاج دلالة ايحائية تتخطى التقريرية الملازمة لكثير من الشعر، فالاستعارة لها القدرة على (احداث خلخلة عجيبة في توقع المتلقي بما يتسع من دلالات وما يضفي من

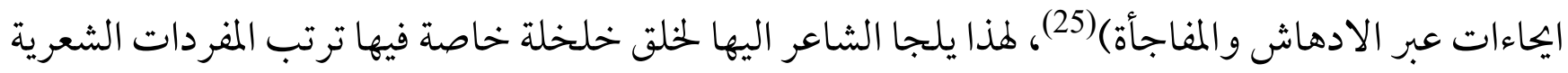

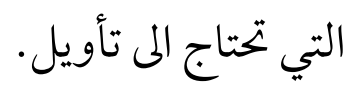

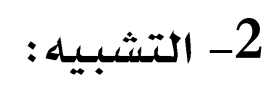

يعد التشبيه من اهم الصور البلاغية التي تعتمد على نظام الانزياح، إذ حظي بمكانه واسعة في الساحة الأدبية

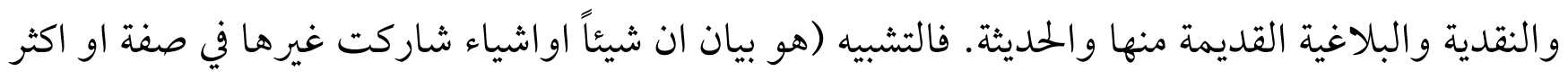


بأداة هي (الكاف) وتقرب بين المشبه والمشبه به في وجه الشبه، يراد المعنى وايضاحه)(26). فهو من الاساليب الادبية التي اعتنى بها العرب بو صفه انزياحاً عن الكلام العادي و المألوف. ومن خلال تقسيم العلماء التقليدي له يبني على دعائم اربع هي اركان للتشبيه وكما يلي: (المشبه والمشبه به واداة التشبيه ووجه الشبه)(27) والعنصر الاول والثاني مما لا يمكن الاستغناء عنها في بناء الصورة التشبيهية، ذلك لأنه بفقدانها يمكن لهذه الصورة ان تتعرض للاختلال و الضعف، اما غياب العنصرين الاخيرين فإنه لا يؤدي المى ضياع التشبيه، بل المى تقويته، وذلك بدفع المتلقي المى التأمل وأيقاظ الذهن لفهم المعنى المطلوب. اذن التشبيه علاقة مقارنة بين طرفين لاتحادهما او اشتراكها في صفة او حالة، او مجموعة من الصفات والاحوال(28) يكون التشبيه من اسباب الانزياح اذا حدث فيه تفاوت بين المشبه والمشبه به، فالتشبيه يعمل عمل السحر في تأليف الاشياء المختلفة والمتفاوتة وكلم) كان التشبيه اكثر تباعداً، كان التشبيه اقوى تأثيراً، ويعلل ذلك الجرجاني يقول (شدة ائتلاف في شدة اختلاف)(29). وهذا التفاوت والاختلاف بين المشبه والمشبه به هو الذي يؤسس لدلالات اشكالية تتفتح على امكانات مطلقة من التأويل والتغيير فتحفز ذهن القارئ وتستثيره ليداخل النص ويتجاور معه ليكشف القارئ فيه ان النص شبكة دلالية متلاحمة من حيث البنية ومنفتحة من حيث امكانيات الدلالة، في مادة للاختلاف (30). اذ ان الانزياح ينبع من تعالق التراكيب المميزة مع العناصر الاخرى والمبدع الحاذق هو الذي يسخر امكانات اللغة ويتلاعب بتركيبها مما يمنح النص خصوصية شعرية تجعله يتميز عن غيره من النصوص الاخرى. فالتشبيه في هذه الحالة (يجعل الصورة تحافظ على قوامها المتعين وتدخل على مستوى التو اصل المنطقي...(31). وهذه الصورة المتكونة من خلال التشبيه والتي يستحضرها المبدع وينزعها من عالم غير محسوس تقوم بتحريك عو امل التصوير لدى المتلقي، كذلك تقوم هذه الصورة بإثراء الاستدعاء الخيالي للنص (32). اما النقد الحديث فينظر المى التشبيه وقيمته على انه (صورة شعرية تقوم على تقريب حقيقتين، فلا ينظر اليه فقط من خلال طبيعة كل حقيقة اذا كانت مجردة او حسية، وانما ينظر الية من خلال عملية التقريب والجمع بحد ذاتها ومع موقع هذا الجمع داخل السياق العام. وما يمكن للعلاقة الجلديدة المستحدثة بين طرفي التشبيه ان 
تولد من ايحاءات ومدلولات جديدة)(33)، وبناء على ذلك فإن القيمة ليست محصورة في التفريق بين الحسب و المجرد كما يدعي البعض، وانها تعدوه الى عملية التقريب بينها. فالتشبيه من ابراز الدلالات الايحائية التخيلية التي تعمل على الاستعحال الحي للغة، التي تثير الدهشة والاستغراب(34). وقد وظف الشاعر يوسف الثالث التشبيه في معظم اغر اضه الشعرية التي وردت في ديو انه لتحقيق القيمة الجمالية للانزياح في شعره، و من ذلك قوله(35):

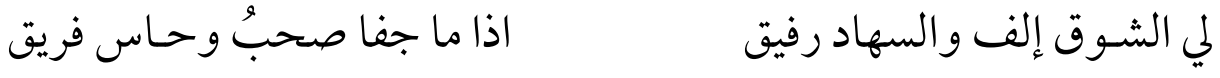

ان حذف اداة التشبيه ووجه التشبيه في هذه النص ادى المى احداث نوع من الفجوة او الدهشة عند المتلقي مما يدفعه الى صورة تشبيهية في خخيلته، إذ شبه الشوق بالألفة وشبه السهاد بالرفيق، فهذه التشبيهات دلاله على مصاحبه الشوق والسهر له وهما صورتان متلازمتان معنويتان تشبهـها بصورة بجسدة (الرفيق والإلف)، فلكي (يكون التشبيه صادقاً في التعبير عن المشاعر الوجدانية، متفاعلاً معها وجب ان يتفاعل طرفاه، بان يكون المراد تشبيهه مرآة تعكس بصدق ابعاده النفسية ومشاعرة الوجدانية وآفاقه النفسية حتى يتمكن من الثأثير في نفس المتلقي وتحريك انفعالاته المناسبة)(36). اذن استطاع الشاعر من خلال توظيف هذه الصورة التشبيهية المركبة والمتداخلة بين ما هو معنوي وما هو حسي (جسدي) تعكس صورة الشاعر المعقدة. ومن الامثلة الاخرى، من قوله(37):

هل البانُ يهكي من معاطفك القدا او الورد في توريده يشبه الخدا لقد أخطأ التشـبيه من حسـب السها يقــــاوم في آفاقه القمر السعدا

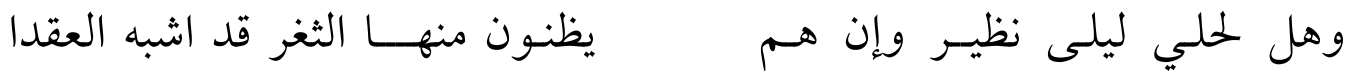

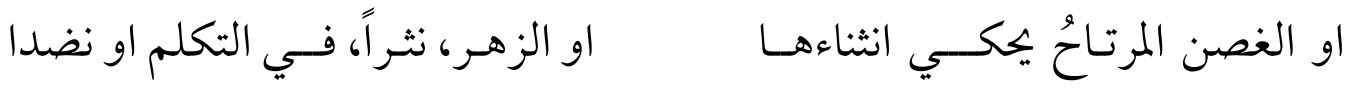
استطاع الشاعر في هذه الابيات ان يطرق انزياحاً غريباً في التشبيه، ربها تكون الغاية منه المبالغة في وصف جمال حبيبته، فلم يجعلها المشبه، بل جعلها المشبه به غالبا ما يكون ابلغ من المشبه، ولهذا نجد الشعراء يشبهون المرأة بالقمر في الجمال، وبالغزال في الرشاقة، وفي هذا جعل الشاعر المشبه (البان)، والمشبه به ( قد) حبيته، وجاء 
بأداة التشبيه الفعل(يحكي) ولم يأت بوجه التشبيه، جعل المشبه (الورد)، والمشبه به (الخد)، وجاء بأداة التشبيه الفعل (يشبه)، وذكر وجه الشبه (التوريد)، فالبان في هذا النص يحكي قدها بدلا من ان يشبه قدها بشجر البان، وجعل الورد الأحمر هو الذي يشبه خدها والغصن الرطب يشبه انثناءها، واصطفاف الزهر في البساتين يشبه انثناءها عند تكلمها، فقد استطاع الشاعر من خلال التشبيه المقلوب ان يبدع في وصف جمال حبيته، فأصبحت تقاسيم ححبوبته لا نظير لها، فهي صورة غريبة غير طبيعية عند الوهلة الاولى على الرغم من ان الخيال عمل على صنعها وتركيبها من اشياء طبيعية محسوسة، (البان، القد، الورد، ا لخد، السها، القمر، الثغر، العقد، الغصن، الزهر) فكل هذه العناصر لها وجود حسي في عالم الطبيعة الاندلسية، وكل ما عملة الشاعر انه اعاد ترتيبها بطريقة خخالفه فيها المألوف فجاءت الصورة التشبيه ذات قيمه دلاليه سياقيه فضلا عن اتصافها بالعمق والإيحاء، وهذا مما يولد بعض الطاقات في ذهن المتلقي التي توصله الى الدلالة المعنوية، (فكلم) استدعت الصورة التشبيه من متلقيها التعامل الذهني واستوجبت منه حق اكتشاف وفض مغاليقها كانت الذ واقعا واعلق بالقلب و الصق بالنفس)(38). ومن قوله ايضاً (39):

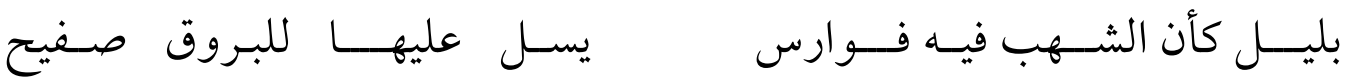

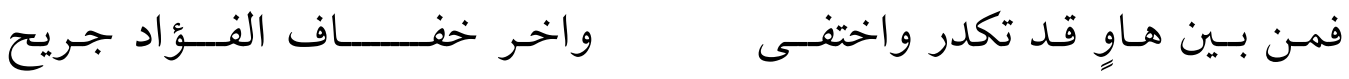

في هذا النص لا تقف تشبيهات يوسف الثالث الضمنية عند التشبيه المفرد، فقد وظف الشاعر تشبيه التمثيلي في هذا البيت لتكثيف الدلالة، اذ شبه الشهب وهي تسقط والبرق في الليل بفرسان على خيلها تحمل في أيديها سيوف براقه لامعة، وهذه الصورة المألوفة المتشابهة ترسم لنا صورة بصورة متحاثلة مع وجود اداة التشبيه، اذ ارتكز عليه الشاعر في استحضار صورة رأتها العين لتوصيل المعنى وتقريبه المى المتلقي، حتى وان كان تشبيه محسوس بمحسوس، لكنه التشبيه الذي يعمل العقل ويستثيره للتخيل وتصور الاشياء في الذهن، وأهم شيء يمكن ان يثير في نفسية القارئ هو وضعه امام عالم جديد من العلاقات كانت غائبه عن ذهنه (40). ومن قوله ايضاً(41):

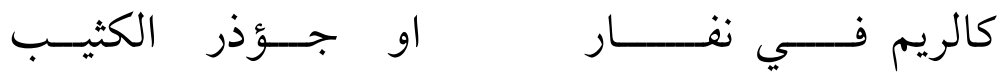




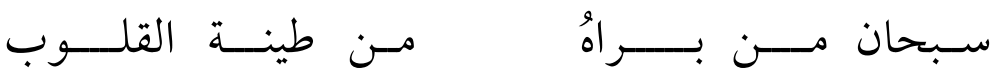

إن ججئ الاداة في اول البيت وسبقها لطرفي التشبيه فيه ايحاء للصورة بدءاً، فهي تعمل على تشويق المتلقي في التطلع نحوها، لأن تركيبها لا يعطي معنى الا بطرفها الثاني لكونه اسما لتلك الأداة، ولذذا فهي تثير في نفس المتلقي نوعاًمن التشويق لمعرفه الاسم، فالشاعر شبه معشوقته بالغزال للخفة، وبالريم للجمال، والجؤذر (ولد البقر الوحشية)،وقد خرج هذا التشبيه عن الكلام المألوف ، اذنرى ان هذه التشبيه له دلالة ايحائية اخرى، فهو يبين نرجسية الشاعر وذاتيته، فإن اداة التشبيه (الكاف) عملت على ابراز عنصر التشويق عند القارئ من خلال تصورها لطرفي التشبيه .ومنها أيضا قوله(42):

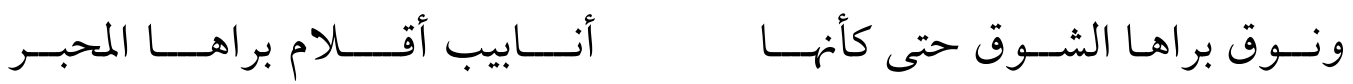
نجد الشاعر يرسم لوحة تصويرية تشبيهية من خلال وصفه للنوق وهي ترحل من ديارها الى ديارٍ اخرى، فالشاعر في هذا البيت يعتمد على الخيال البصري، حاول الشاعر ان يشد انتباه المتلقي من خلال إعطاء النوق صفه إنسانية وهي (الشوق) ويستعمل الفعل (برى) وهو يرتبط بتشذيب الاقلام في الكتابة مما يجعل الاداة اكثر ضعفا وحدة، فكان الواسطة لتغريب التآلف والانسجام بين الصورتين، فالشوق يبرى النياق والمحبر يبري الأقلام، واشتراك الصورتين بحالة الضعف والهزالة كانت مدعاة لتحفيز خيال الشاعر، واستدعائه لل ل اجمع بينها على الرغم من الاختلاف الواسع بينها.

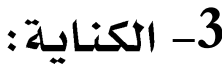

تعد الكناية فن من الفنون البلاغية التي يبرز فيها معنى المعنى، المر اد بها بطريقة جميلة بديعة غير مباشرة، وهي من اروع واجمل فنون علم البيان، وهي بلاغة عجيبة تدل على المعنى من دون ظاهرة لفظة(43)، تلعب الكناية دور اساس في عملية الابداع الفني، الى ان الكناية تلازم اتجاه نقدي في مدى تأثيرها في خلق الانزياح وتكوين الابداع، فالكناية تقوم في جوهرهاً بأحداث الفجوة (مسافة التوتر) بين (المعنى ومعنى المعنى)، الاول يحمل معنى الدلالة والثاني يحمل معنى التلميح(44)، لا تنشا الكناية على صعيد المكونات اللغوية الجزئية فقط، بل 
تنشأ على المو اقف الفكرية والرؤى الكلية، التي ينتج منها النص الشعرية. تناولها عبد القاهر الجرجاني في كتابة (دلائل الاعجاز) وعرفها بان (يريد المتكلم إثبات معنى من المعاني، فلا يذكره باللفظ الموضوع له في اللغة ولكنه يجئ معنى هو تاليه وردفه في الوجود، فيؤمن به اليه، ويجعله دليلاً عليه، مثال ذلك قولهم: فلان كثير الرماد، يريدون كثير القرى)(45)، وتعريفة هذا يعد من اكثر تعريفات الكناية نضجاً، وقد ساق امثلة كثرة ليخدم بها فكرتة المطروحة امام هذا المصطلح، (فالنصوص الكنائية عنده اصبحت فناً ينبض بالحركة والحياة، فالجر جاني يستعمل منها اشكالاً ادبية حية، ثم يناظر بينها ويفاضل، مطبقا نظريتهُ التي تقوم على نظم الكلام وتركيبه)(46)، وهو بذلك يريد من الكناية إثبات المعنى الثاني الذي يستفاد من المعنى الاول للفظ، لا من اللفظ نفسه، فهو لا يثبتها عن طريق اللفظ الموضوع لها في اللغة بل من المعنى الذي يتكئ على المعنى الاول(47)، ويردف عبد القاهر الجرجاني قائلاً في فضل الكناية في الكلام، وعملها في عملية النظم والمعنى فيقول: (هذا فن من القول دقيق المسلك، لطيف المأخذ، وهو انا نراهم كما يصنعون في نفس الصفة بان يذهبوا بها مذهب الكناية والتعريض، كذلك يذهبون في اثبات الصفة هذا المذهب، واذا فعلوا ذلك بدت هناك محاسن تملأ الطرف، ودقائق تعجز الوصف، ورأيت هناك شعراً شاعراً، وسحرا ساحراً...)(48). ولعلنا لا نحتاج المى كبير جهد في تقدير مدى ارتباط عنصر الكناية بمفهوم الانزياح، إذ ان الانزياح ماثل اثناء التعريفات التي عرفت بالكناية، وخير دليل على ما بين ايدينا من تعريف الجرجاني لها، فهذا التعريف يدلنا على وجود الصلة الوثيقة بين الكناية والانزياح إذ إنه يشير إلى ان (المتكلم يعدل عن التصريح بالمعنى المر اد اثباته المى ذكر ما يلزم عن هذا (المعنى)(49)

هناك ترابط بين الكناية والاستعارة، فقد مزج الناقد الغربي جاكوبسن بين المصطلحين قائلاً (ان العوقين الرئيسين المتقابلين في ثنائية وهما عوق المشابهة وعوق المجاورة يرتبطان ارتباطاً كليا بصنفي البلاغة والاستعارة والكناية...)(50). فمن خلال قول جاكوبسن يتضح ان الكناية تعمل على تحقيق نفس الخرق الدلالي الذي تقوم به الاستعارة، وذلك من خلال السياق الواضح المكشوف لدى المتلقي القارئ، حيث ان الكناية لا تشكل ججالاً كبيراً لمدركات القارئ والمتلقي بشكل واضح. 
فالغرض من استعحال الشاعر فن الكناية هو ان ينظم نصه ويحاول ان يضيف الى هذا النص لمسة فنية تكمن في خلق رؤية جديدة تؤثر في نفس المتلقي اي (إنها تقدم للمتلقي تجربة الشاعر الادبية بصورة غير مباشرة، بشكل مؤثر في نفس المتلقي وبصياغة ادبية جميلة، تتضافر فيها مكونات الصورة جميعها لتشكل في النهاية نسيجاً لغوياً يتم من خلاله نقل الفكرة المراد تبليغها)(51). وقد استعملها الشاعر يو سف الثالث في قصائده، لما لها من قوة خفية في الثأثير في نفس السامع، فهي تعمل على اثارته وجذب انتباهه للوصول الم المعاني الخفيفة التي تعبر عنها، ويمكننا ان نقف عند بعص الامثلة الشعرية

$$
\text { التي وردت في ديو انه، ومنها قوله(52): }
$$

ومنعمسه الاطـراف ساقية الحشى مرجرجـه الارداف خخطفة الخصـر

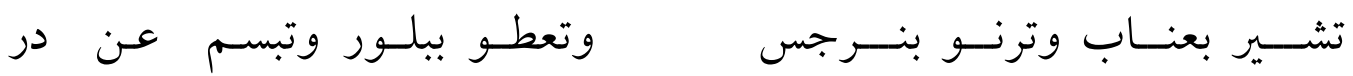

صور الشاعر حبيته من خلال اسلوب الكناية عن الصفة، اذ جعل لحبيبه أروع الأوصاف الجسدية، فمن صفات الجمال التي رآها الشاعر في حبيبته ضمور الحشى وطول قامتها وخصرها دقيق جداً، ومن هنا نجد ان الكناية تحمل في طياتها رمزاً وإيحاء من شأنه تنشيط الخيال واثارة انتباه المتلقي لتحقيق غاية بلاغية خفية(53)، فالقارئ (لا يجد متاع نفسه في السياق الواضح جداً والمكشوف الى حد الشعرية .... ، انم) يجد متعة نفسه حيث يتحرك خياله وينشط ذهنه، ليستوضح ويتبين ويكشف الاسرار والمعاني وراء الايهاءات والرموز، وحين يدرك مراده ويقع على طلبته من المعنى يكون ذلك امكن في نفس واملك لها من المعاني التي يجدها مبذولة)(54)، فهذه الكناية صورة رمزية تجعل القارئ يسافر بخيالة وسط المعاني لفك مغاليقها وايحاءاتها، وقد حاول الشاعر في هذا النص ان يبرز للسامع جمال الصورة وما توحي لهُ من صفات جمالية لدى حبيبته.

$$
\text { ومن ذلك قوله أيضاً((55): }
$$

فقد حقق الشاعر في هذا البيت انزياحاً وخروجاً عن المألوف وحقق رؤيته من خلال قوله (نؤوم الضحى) وهي كناية عن صفة حبيته، اذ ار اد ان يذكر طبيعة الحياه التي تعيشها هذه الحبيبة، فهي تعيش في ترف ولها من 
يخدمها، فاستطاع الشاعر ان يعبر عحا يدور في ذهنه عن تلك المحبوبة من خلال الكناية الوصفية التي كانت وسيلته لنقل الصورة وتوضيحها الى المتلقي، فتأثير الكناية في هذا النص يبرز لنا من خلال نقل المحبوبة بدلالات وايحاءات تعبر عن نمط الحياة التي تعيشها ،فالشاعر قد رسم صورة جميلة تعبر عن حبيبته المرهفة والمنعمة فلا تستيقظ من نومها الا في ضحوة النهار. ومن قوله ايضاً(56):

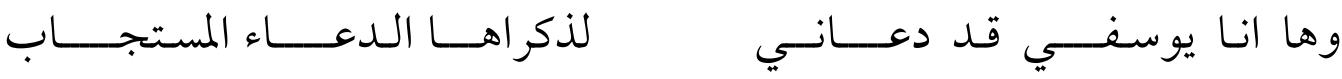

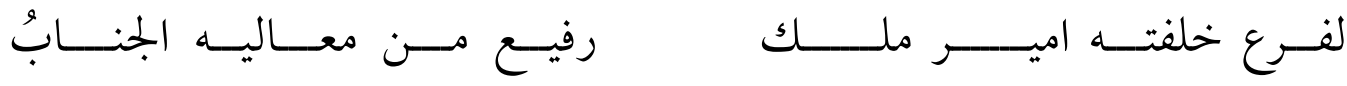

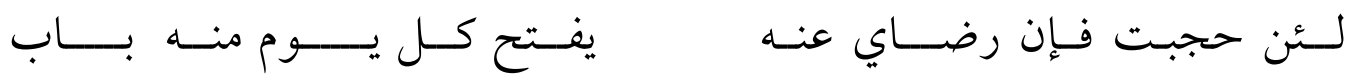

فقد رسم الشاعر لنا في هذه الابيات لوحه فنية تعبر عن حزنه وعن معاناته النفسية الجياشة، اذا استعمل الشاعر أسلوب الكناية عن الصفة بقوله (فرع) كناية عن ان ابنه مازال غصنا صغيراً، فالشاعر يشبه ابنه بالغصن الذي يتفرع من الشجرة، ونلمح في هذه الابيات حزن الشاعر على وفاه زوجته، وابنه الصغير الذي خلفته وراءها، ولعل تدفق خيال الشاعر وصدق عو اطفه واحاسيسه ومشاعرة اثر في نفسه، اذ عمد الشاعر المى هذا التركيب الكنائي التشبيهي لتعبير عما يدور في ذهنه من معنى، (لتدل على معاني التصوير منطلقة في كل شكلياتها من المفردة لا من حيث دلالاتها وايحاءاتها وانها يجد لها مع بعضها داخل السياق الواحد)(57.) ومن الامثلة الاخرى قوله(58): - (25)

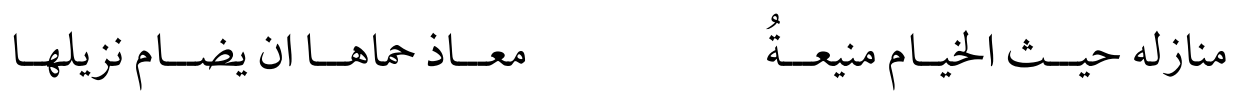
يتضح من خلال هذا البيت الوظيف القائمة على كناية الصفة، إذ نسب الشاعر صفات المنعة والحماية الى الممدوح حيث يقودنا الم شيء متصل بالممدوح هو المحور الذي يدور حوله النص، وقد جاءت الصورة الكنائية واضحة على انه ملك قوي مهاب الجناب، منازله و حماه منيعة على الاعداء ولا يضام من يستجير به، فاستطاع الشاعر ان يعبر عن المعنى الحقيقي لإيصاله الم المتلقي،وهذا يدل على ان (عنصر اللامعقول يعد ضروريا في الشعر، لكن لا يستحيل الم عبث الذي لابد من دفعه للوصول الى الوضوح من نوع جديد، واذا فقدت الكلمات معناها على مستوى ما فلكي تعود و تكتبه على مستوى اخر (59). 


\section{ومن قوله ايضاً(60):}

هــــه هـــــه اخـــوه ملـــك

ان قول الشاعر (فارغ النجد مستطيل النجاد) يشد انتباه المتلقي، اذ ان المعنى الحقيقي لهذه الجملة توحي لنا ان الموصوف طويل الحجم ومماثل لسيف طويلة، فالشاعر هنا يستعمل الكناية الموصوفة ليحفز خيال المتلقي لان سياق البيت لا يستقيم مع هذا المعنى ويوحي بمعنى اخر، فهو يكنى بصفات (القوة والماضي الطويل المليء بالمعارك البطولية) ولقد أراد الشاعر يوسف الثالث ان يستدعي بهذا البيت صورة كنائية يبرز فيها بعض التأمل من خلال الصورة الذهنية التي تتجاوز الحد المعقول المى المعنى الحقيقي المطلوب، ودليل على ذلك ان نجاح الشاعر في احداث او تحقيق حالة التوتر (الصدمة) لدى القارى، لان الكناية (ليست اداة معنى بألفاظ لا تدل على ظاهر مدلو لها فقط، وإنما هي صياغة فكرة تنبع من وجدان صاحبها، فتتماسك الفاظها وتنسق تعبيراً لكل لفظ منه مكانه ووشيجته التي تربطه بجا اتى قبله وبها يرد بعده فيو مض بالمعاني والاحاسيس إيحاضاً لو تزعزع ذلك اللفظ او سواه عن مرفعه لعجز التعبير عن اداء مهمته البلاغية )(61). ومن الامثلة الاخرى قوله (62):

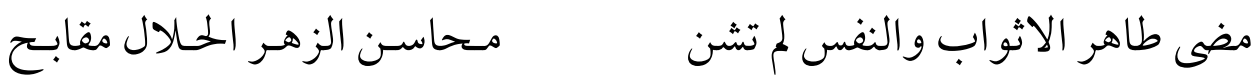
استطاع الشاعر من خلال هذا البيت ان يوظف الكناية كعنصر فاعل من عناصر الصورة البلاغية، فالشاعر يصف طهارة الاثواب ونقاؤه، يراد به طهارة النفس وعفتها، فانزاح الشاعر بلفظه (الاثواب) التي تشير الى اللباس الذي يستر عورة الإنسان، وهذا هو المعنى لكلمة الاثواب، الا ان الشاعر انزاح الى ما يلزم عنه وهو طهارة النفوس، حيث استخدم الشاعر الكناية عن نسب ليحفز ذهن المتلقي (لان نسب الطهر للثياب يريد به نسبة الطهر المى صاحبة، فإن طهارة الثوب كناية عن طهر صاحبه وعفته، والطهارة هنا معنوية، وليست حسية، المقصود بها طهر النفس)(63)، ومن هنا فإن قدرة الشاعر وتمكنه في ايصال المعنى تحقق قيمه دلالية تثير في نفس المتلقي. 
ومن هنا فإن الانزياح الكنائي في النص الشعري يؤدي دوراً مها في الكشف عن قدرة الشاعر ومهارته وقناعته ببراعة القارئ لفهم المعاني التي تدور وراء الايحاءات والرموز المخفية، لان النص الشعري يتمثل في (الايحاء عن طريق الصورة الشعرية لا بالتصريح بالأفكار بجردة ولا بالمبالغة في وصفها، تلك التي تجعل المشاعر والاحاسيس اقرب الى التعميم والتجريد منها الى التصوير والتخصيص، ومن ثم كانت للصورة اهمية خاصة)(64).

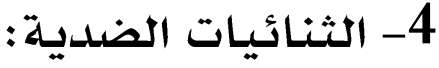

تعد الثنائيات الضدية من الفنون البديعية التي تجلت في ديوان يوسف الثالث مستدلة بألو ان وتراكيب وصور من خلال ظاهرة التضاد، الا انها الثنائيات الضدية وليدة فكر معرفي يتحرك، وينسج مسار حركثه، وثمة ثنائيات كثيرة لها اشد الحضور في حياتنا، فلا وجود لشيء من دون نقيضه، اما اللغة فهي اداة تحقيق معاني الحياة وجوهرها(65). فإن ظاهرة الثنائيات الضدية واحدة من اهم الظواهر الفكرية والفنية التي يمكن معاينتها ورصدها في إبراز الدلالة المركزية في النص، إذ يتخطى المدلول الاول القراءة وصولاً المى المدلول الثاني الذي يمثل البنية العميقة للمعنى، وهذا النسق يقوم بخرق المألوف وتحقيق انزياحات اسلوبية من خلال خلق جو من التناقضات والمتنافرات اذ تصبح اللغة الشعرية المكثفة ركيزة النص وهي التي تميز بنيته النوعية لتحقيق حضوره من خلال تقاطع الدوال بالمدلولات، بل ان العلاقة بينها ليست بعيدة فقط وانها متناقضة ومتنافرة (المزج بين المتنافرات وصهرها في كيان واحد يعانق فيه الثيء نقيضه، فيتفاعلان في سياق دلالي يطبعه التنافر تعبيراً عن حالات الواقع المتناقض، وتجسيداً لما يعتمل في نفس الشاعر من احاسيس غامضة ومشاعر متضادة)(66).

وقد وقف البلاغيون على مصطلح الثنائيات الضدية التي نجدها تتراوح في معناها الضدي ما بين مصطلح الطباق و التضاد والتكافؤ والتقابل. وتحدث عبد القاهر الجرجاني يتحدث عن اهمية التضاد في تشكيل الصورة الفنية قائلاً: (وهل تشك في انه يعمل عمل السحر في تأليف المتباينين حتى يختصر لك بعد ما بين المشرق 
والمغرب، ويجمع ما بين المشئم والمعرق...)(67). خاطب الجرجاني العقل في اثناء كلامه على التضاد ومعنى ذلك انه يدرك اثر الثنائيات الضدية المتشكلة ضمن انساق ضدية في خلق المعنى في النص. فالتضاد نزعه عقلية في النهاية، ويدرك الاثر النفسي الذي يولده اجتماع الضدين لدى المتلقي (68). ومن خلال هذا الطرح الدلالي يمكن القول ان هذه الثنائيات ترتكز على ازدواجية الرؤية من خلال قيامها على الجمع بين الشيء ونقيضة التي يلجأ إليها الشعراء(69)، اي ان اللغة الشعرية عند كمال ابو ديب تعمل على تشابك الدوال في علاقات مستمرة مع لغة التضاد الأسلوبية والتي تعد (احد المنابع الرئيسة للفجوة -مسافةالتوتر)(70). فالثنائيات التي لا يحدث مع اجتماعها تناقض بارز على سطح بنيتها لا تشكل انزياحاً لسلامة بجيئها في موقعها لان (الشعرية جوهريا لا خصيصة تجانس وانسجام وتشابه وتقارب بل نقيض ذلك كله، اللاانسجام و اللا تشابه واللاتقارب، ...)(71). من خلال تصفحنا لديو ان شاعرنا كانت الثنائيات تشع بالإثارة الدلالية والسياقية لدى القارئ، ومن ذلك قوله (72): ولكـن هــذا الشـهر قـد زادنا بعـداً خليلي ان الــدار اضـحت قريبة ومن قوله ايضاً(73) (20) ومن يصنع المعروف في غيـر اهله وظف الشاعر الثنائيات لخدمة المعنى من خلال جمعة بين لفظتي (قريب - بعيد) و(السر - الجهر) فالتضاد يستشف المعنى الخفي في السياق اذ يضفي على النص لونا من التعتيم، ليبعث الاندهاش في نفس المتلقي (74)، فالشاعر اراد في هذه الالفاظ (القريب - البعيد) و(السر - الجهر) ان يعبر عن حاله فهو يقترب من قومه، وهم يبتعدون منه، وهو يقترب من الحبيب والحبيب يبتعد عنه، و هذا كله يصور لنا الحالة النفسية لدى الشاعر، الذي يؤكد ان شعره لم يكن منفصلاً عن ذاته واناه، بل جاء معبراً عن همومة، واحزانه، وآماله، وآلامه(75)، (وهذا يعمل على إيحاءات ترفع بالقارئ الى البحث عن البنية العميقة للنص)(76). ومن الامثلة

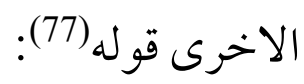




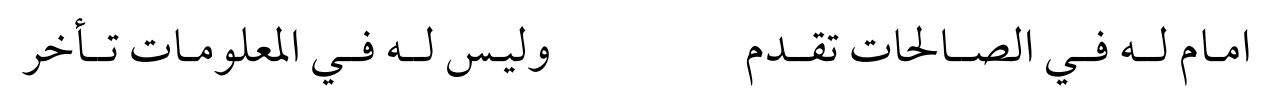

الثنائيات التي وردت في سياق النص، حققت انزياحاً اسلوبياً حول بنية دلالية اساسية هي بنية التغير و التحويل من الايجاب الى السلب، وبالعكس، وقد وظف شاعرنا الثنائيات المقابلة لخدمة المعنى من خلال الترابط بين الثنائيات (تقدم، تأخر) وهذه الثنائيات تحمل في طياتها دلالات وانفعالات، وهنا ان هذا لا يشير الى بروز السياق فحسب، بل يحدث انكسار في بنيه النص، عبر الجمع بين المتناقضات التي تبدو متنافرة لغوياً، لأنها تعمل على إحداث سلسلة من المفاجأت والصدمات التوترية جراء المقابلة بينها، لكي (يخلق صوراً ذهنيه ونفسية متعاكسة يوازن فيها بينها عقل القارئ ووجدانه)(78)، فضلا عن هذا فإن السمة التنافرية تعمل على ابراز حاله الشاعر المبدع التي يستثمر الطاقات الكامنة في كل نص أدبي. ومن قوله ايضاً (79):

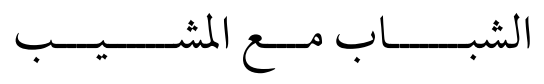

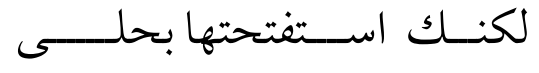

استهل الشاعر قصيدته على اساس المقارنة التقابلية بين مفردتي (الشباب، والمشيب)، لتشكل خلخله في فكرة البنية اللغوية القائمة على تجلى بنية التقابل فهذا النص قاد الشاعر الى استرجاع الماضي والحاضر ولحضاته الجميلة التي اثرت في شبابه، وهذه المنافرة اللفظية تجسد انزياحا لغويا شعريا يصعب معرفه دلالتها المتقابلة، ان الثنائيات في هذا النص هي ازمة الشاعر، فقد تأخذ صورة سؤال الشباب والمشيب، صوراً لا تنتهي في كل اشعاره، فالشاعر يذكر في هذا النص ماضي الشباب، ليخرج منها بمعنى جديد(80). ومن ثم جاءت ابيات اخرى متقابلة ترسم لنا الحزن في قلب الشاعر فيصور عن ذلك الحزن من خلال استخدامه الثنائيات قائلاً(81):

$$
\begin{aligned}
& \text { لا تغتــرر بســرور زائسل فلـهـ بعسـد السـرور اذا ادبرتـه حسـزن }
\end{aligned}
$$

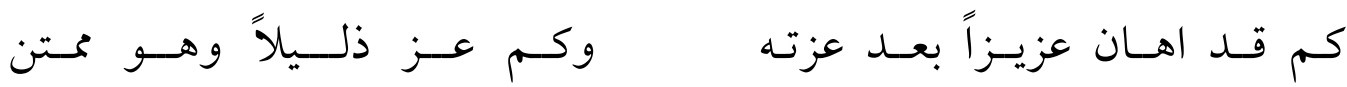

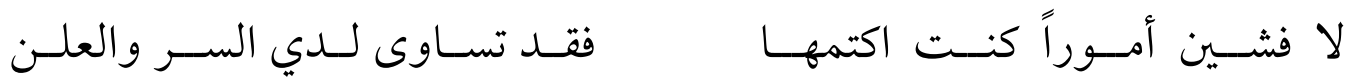


لقد عبر الشاعر في هذه النص عن حاله المضطربة عن طريق استعاله للثنائيات المقابلة فكانت معانيه مغايرة للمألوف، لانها تحمل في طياتها خصيصة عدم التجانس واللاانسجام واللاتشابه واللاتقارب وهذه من اهم السمات الشعرية فاستطاع الشاعر ان يعبر في هذا النص، عن علاقة الانسان بالزمان، فكل مرحلة يمر بها الانسان لها تأثير في حياته وقد استطاع الشاعر التأثير في نفس المتلقي عن طريق استعاله لهذه المتضادات المتنافرة غير المنسجمة، التي تحمل في طياتها معاني مؤثرة استطاع الشاعر توصيلها عبر بجموعة من الثنائيات المقابلة منها (سرور، الحزن) و(اهان عزيزاً) و(اعز ذليلا) و(عزته متهن) و(السر، العلن) ومن هذا الصفات المتقابلة بين ان الدهر يقلب احو ال الناس، فلم يعد يخشى شيئاً بعد ذلك ويعلن امام الزمان عن الاشياء التي كان يحرص على سرها، ومن هنا يمكن القول: (ان قيمة التقابل الاسلوبية تمكن في نظام العلاقات، الذي يقيمه بين العنصرين المتقابلين وعلى هذا فلن يكون له اي تأثير مالم يتداع في ثوال لغوي ويعبارة اخرى: فإن عمليات التضاد الاسلوبية تخلق بنية، مثلها في ذلك مثل بقيه التقابلات المثمرة في هذه اللغة)(82). ومن هذا يكتسب التقابل اهمية متزايدة في هذه الابيات، اذ انه يلقى الحزن في كل اجواء القصيدة ويعمل على اغواء القارئ، لاستباط الثنائية الأساس (الشاعر، الزمان) المتوازية بين هذه الثنائيات التي تمثل إشارات صانع التقابل (الشاعر)، فبينم) يغريه الزمان بالسرور ويفاجئه الدهر يقلب احوال الناس(83). ومن الامثلة الاخرى في قوله(84): - (2)

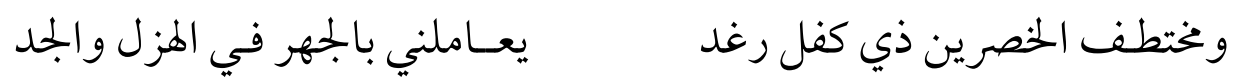
فالتقابل في البيت حصل بين (الهزل) و( الجلد)، فقد جاءت هذه العلاقة بصيغه علائقية تنافريه بين الدوال المتنافية، من حيث بجيئها في هذا النص المألوف فمن غير المألوف ان الجلد يولد الهزل، فالعلاقة بين الدوال متناقضة ومتنافرة، لان هذا التنافر يكشف تصادم بين العلاقات التي تولد في نفس المتلقي شعوراً بالانزياح، ولكن مها حصل بعد بين الدال الاول عن الثاني لابد من وجود ترابط بينها يخلق انزياحا أروع واجمل، ويصبح النص وحدة دلالية (وبذلك يخرج الكلام الشعري عن بجرد الوظيفة البلاغية الى الوظيفة التأثرية)(85). 


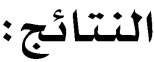

ومن هنا يمكن القول ان الانزياح الاستبدالى، احدث فجوة و تنبيه ليحفز ذهن المتلقي، عن طريق النصوص الشعرية، اذ نلحظ ان استعال الشاعر للصور الاستعارية، والتشبيهية، والكنائية، والثنائيات، كان له دور مهم في مفاجأة المتلقي، فقد يلجأ إليه الشـاعر بدلالات وإيحاءات جديدة في النص عبرت عن رؤية افكاره ومشاعـره الداخلية، فمن خلال دراستنا للانزياح الاستبدالى توصل البحث الى ان قيمه الانزياح في شعر يوسف الثالث تجاوز المستوى اللغوي المباشر، لأن القارئ يجد متعه نفسه حين يخوض بأفكار واساليب لغويه جديدة.

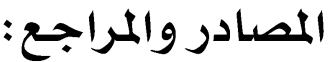

1. أبو العدوس، يوسف مسلم .التشبيه والاستعارة من منظور مستأنف ، ص:104-103 ملكة الكتب الحصرية ،2019م.

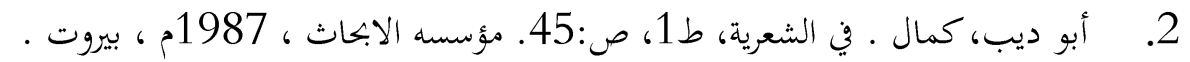

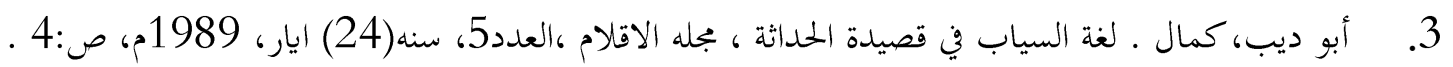

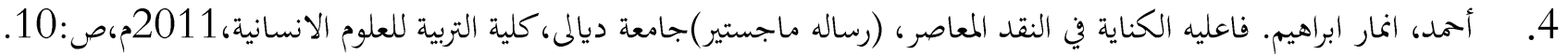

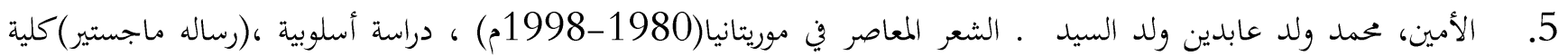
الآداب ،جامعة الموصل ،2000م،ص: 140.

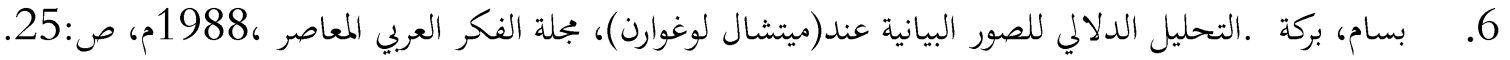

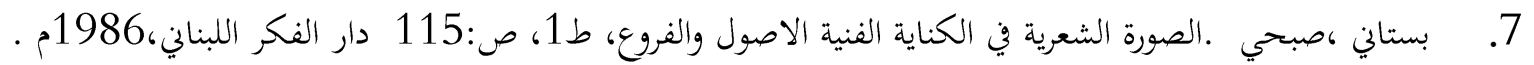

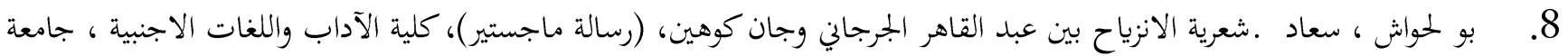

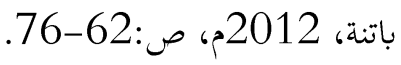

9. بودوخة ، مسعود. الاسلوبية وخصائص اللغة الشعرية. ط1، ص:43.عالم الكتب الحديثة ، 2011م ، الاردن .

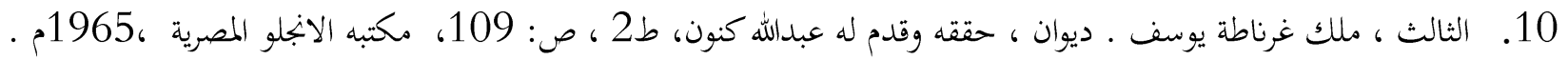

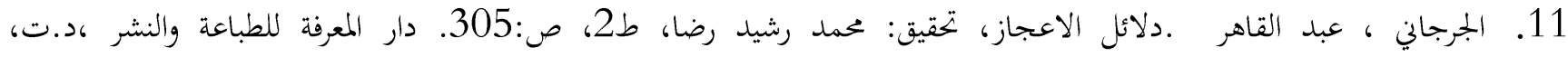
بيروت، بلبنان.

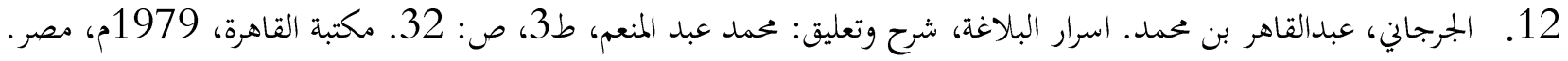

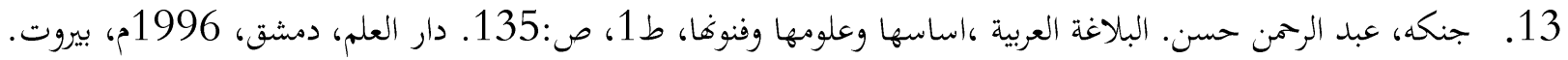

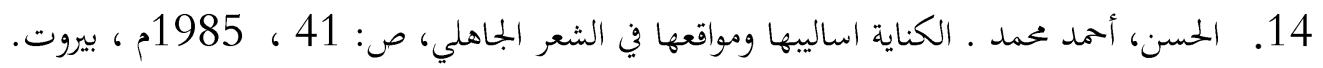


15. مداني، اياد عبد الودود عثمان. شعرية المغايرة دراسة لنمطي الاستبدال الاستعاري في السياب .ط1، ص:25-26. دار الشؤون

$$
\text { الثقافية، 2009م ،بغداد. }
$$

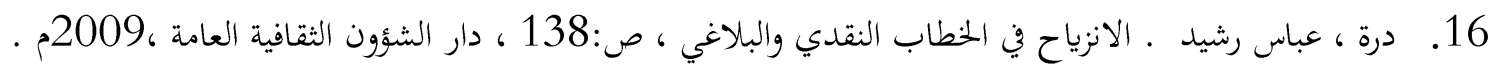

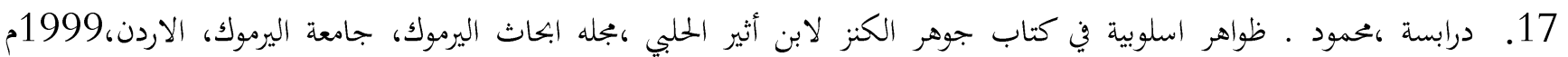

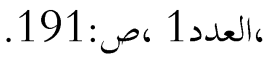

18. درة ، عباس رشيد، البناء الشعري عند مسلم بن الوليد، (رساله ماجستير) كلية الآداب ،جامعة بغداد،1992م،ص:142 .

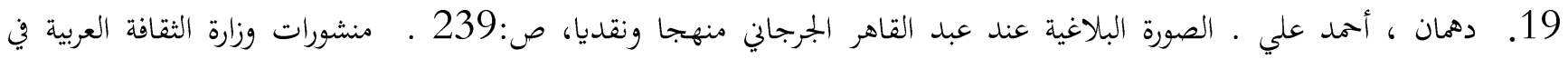

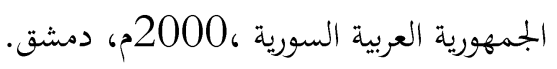

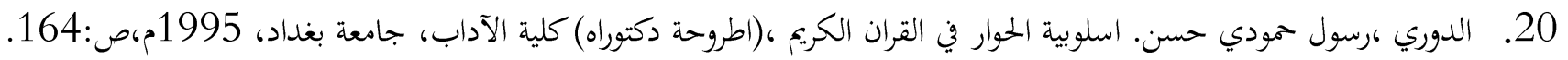
21.

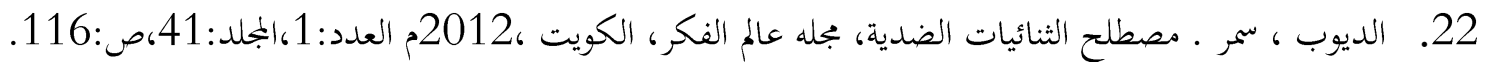

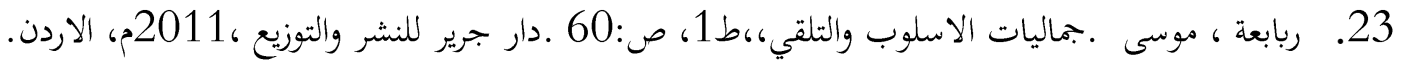

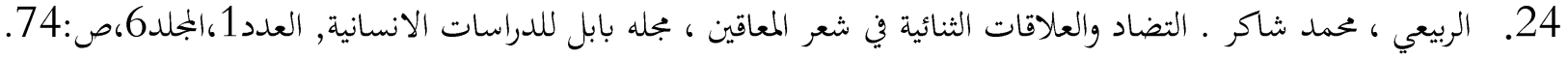

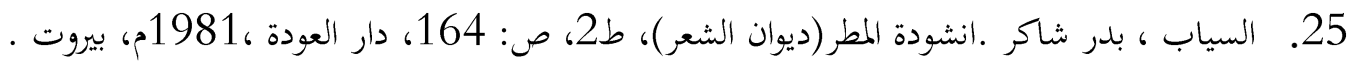

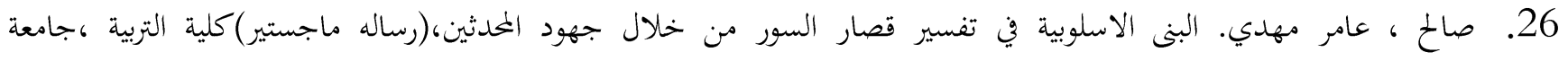

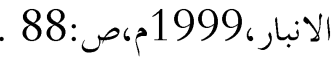

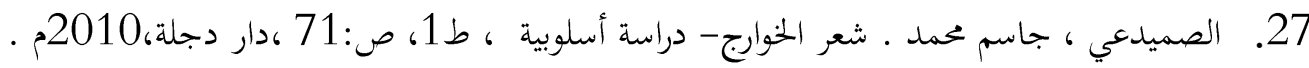

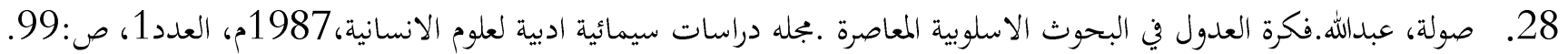

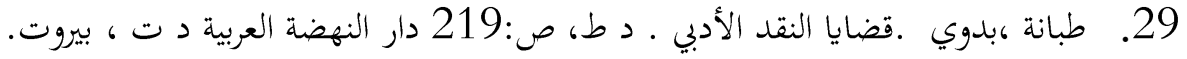
30. الطرابلسي، محمد الهادي.خصائص الاسلوب في الشوقيات، ص:143. منشورات الجامعة التونسية، طبع بالمطبعة الرمية للجمهورية التونسية، 1981م. 31. عبابنة، سامي محمد. التفكير الاسلوبي رؤية معاصرة في التراث النقدي والبلاغي. ط1. ص: 176. عالم الكتب الحديثة، 2007م، الاردن. 32. عبد المطلب ، محمد . البلاغة العربية قراءة اخرى ـ ص:187 .الناشر مكتبه لبنان ،1997م، لبنان.

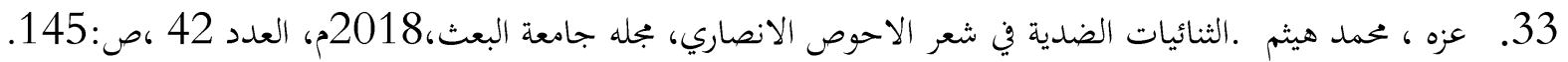

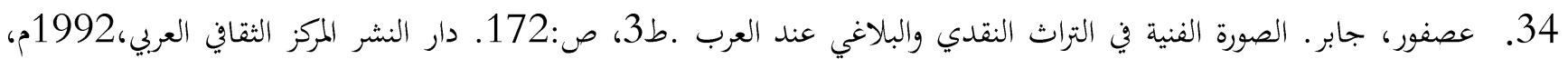
لبنان، بيروت. 35. عطوي ،رفيق خليل ـ صناعة الكتابة (علم البنان) ، ط 1، ص:21. 218 دار المعلم للمايين ، 1989م ، بيروت ، لبنان .

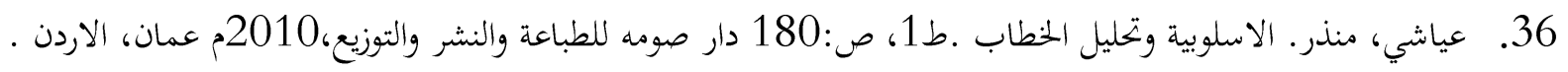

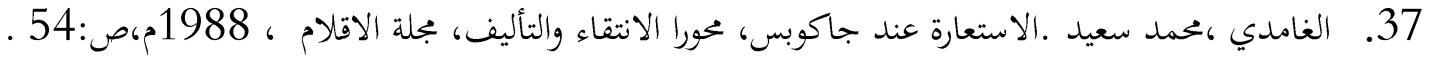


38. الغذامي، عبدالله محمد. المشاكلة والاختلاف، قراءة في النظرية النقدية العربية وبحث في التشبيه المختلفة، ط1، ص:6. الدار البيضاء،

1994م، بيروت.

39. فضل ، صلاح .علم الاسلوب مبادئه واجزائه. ط1، ص:259 ـ دار الآداب، 1995م، بيروت، لبنان.

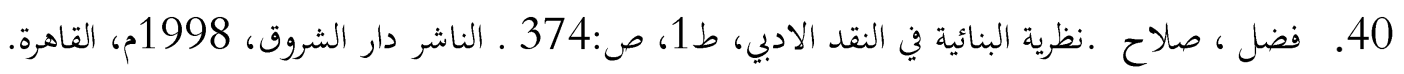

41. قبيلات، نزار وعلي الشروش. الثنائيات، دراسة في شعر محمود درويش، مجله دراسات، العلوم الانسانية والاجتماعية، 2011م العدد3،ص:1000.

42. قطوس ،بسام موسى .الاستعارة التنافية في نماذج من الشعر العربي الحديث ، جامعة مؤتة للبحوث والدراسات ،1994م. المجلد9، العدد4، ص:52.

43. كاظم ، مشكور حنون ـ ملامح الشعرية في النقد الادبي الحديث، مجله جامعة كربلاء العلمية، 2008م،العدد6، ص:129 ـ .

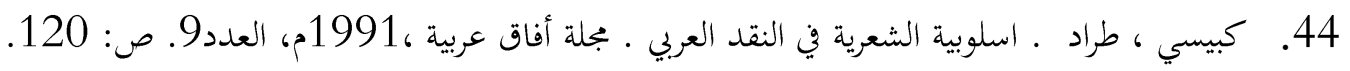

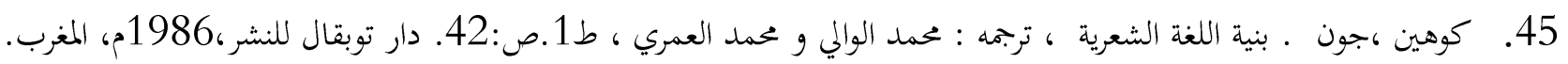

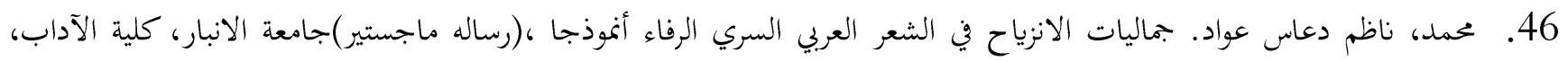

.128:2014

47. المسدي ، عبدالسلام .الاسلوبية والاسلوب .ط5. ص:84-85 دار الكتب الجديد المتحدة 2006م ، بيروت، لبنان .

48. مطلوب ، احمد ود. كامل حسن البصير،البلاغة والتطبيق، ط2، ص: 123، وزارة التعليم العالي البحث، 1999م .

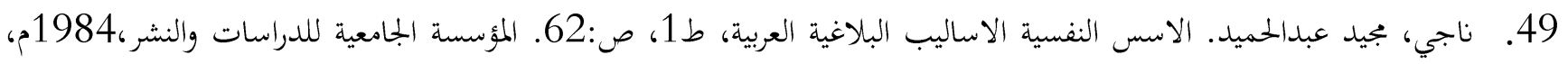
لبنان

50. ناصف، مصطفى. الصورة الأدبية ـ ط3، ص:148.دار الاندلس للطباعة والنشر والتوزيع 1996م، بيروت، لبنان. 51. نجا، اشرف محمد. قصيدة المديح في الاندلس، قضايا الموضوعية والفنية (عصر الطوائف)، ط3،ص:325. 325. الدار الوفاء لدينا الطباعة والنشر، 2003.

52. الهاشمي ،احمد .جواهر البلاغة، تح: يوسف العميلي. د.ط، ص:287 .المكتبة العصرية ، دت، بيروت، لبنان.

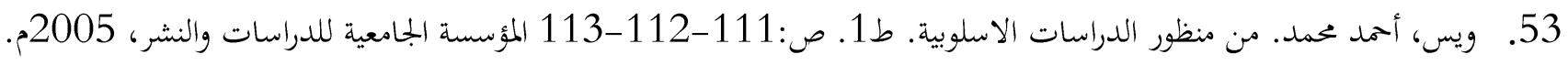

\section{الخهو امهث:}

(1) عياشي ،منذر ـ الاسلوبية وتحليل الخطاب .ط1، ص:180 دار صومه للطباعة والنشر والتوزيع،2010م عمان، الاردن.

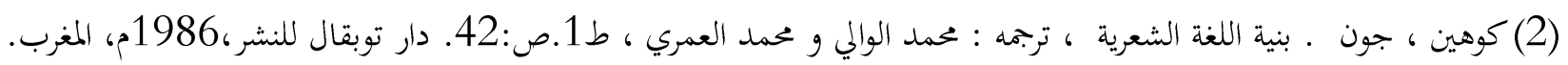

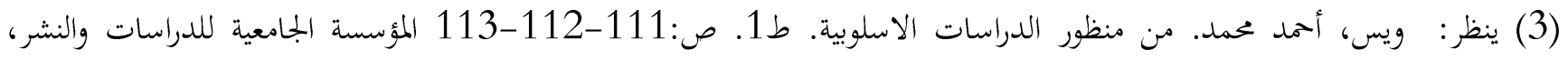

$$
\text { (4) طبانة، بدوي. قضايا النقد الأدبي بيروت ـ د ط، ص:219 دار النهضة العبية د ت . }
$$

(5) ناصف ، مصطفى ـ الصورة الأدبية ـ ط3، ص:148.دار الاندلس للطباعة والنشر والتوزيع ،1996م، بيروت، لبنان. 
(6) ينظر : بدوخة ، مسعود ـ الاسلوبية وخصائص اللغة العربية. ط1، ص:43.عالم الكتب الحديثة ، 2011م ، الاردن .

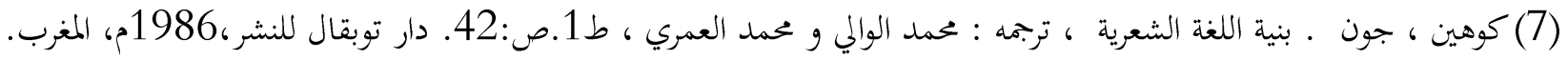

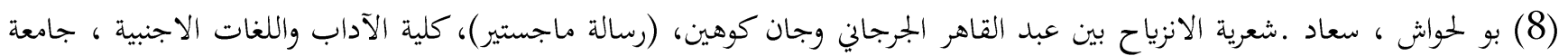

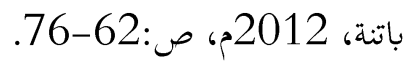

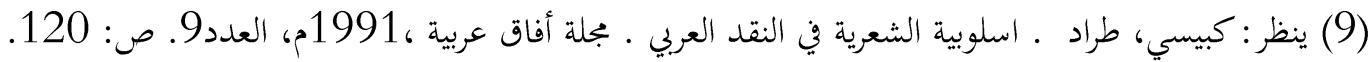

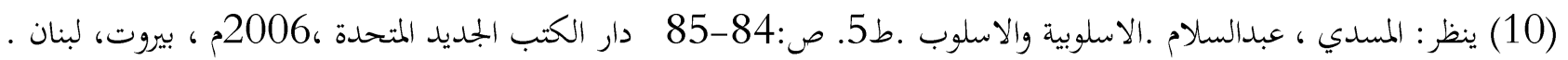

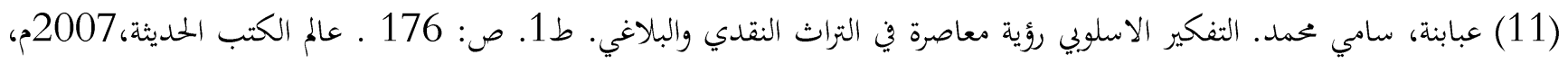
الاردن .

(12) بسام، بركة .التحليل الدلالي للصور البيانية عند(ميتشال لوغوارن)، بجلة الفكر العربي المعاصر 1988م، ص:25.

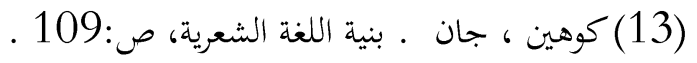

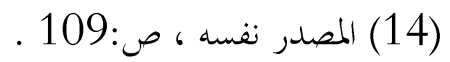

(15) ينظر: قطرس، بسام وموسى ربابعة. الاستعارة التنافرية في نماذج من الشعر العربي الحديث، مؤتة للبحوث والدراسات،1991م.

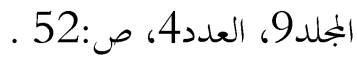
(16) الاسلوبية والاسلوب، ص:105.

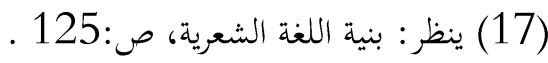

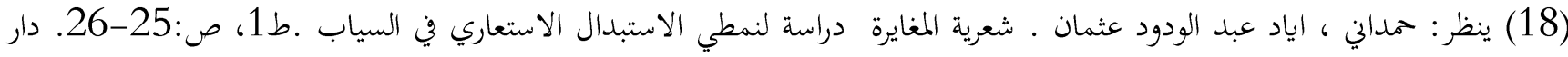
الشؤون الثقافية ، 2009 م كبغداد. (19) دره ، عباس رشيد الانزياح في الخطاب النقدي والبلاغي ، ص:138 ، ، دار الشؤون الثقافية العامة ،2009م . (20) المصدر نفسه ،ص:138.

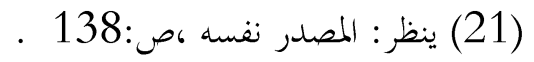

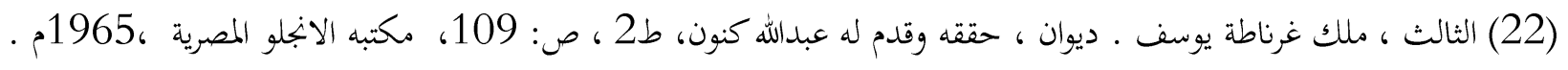
(23) المصدر نفسه، ص: 319 . (24) (25) المصدر نفسه، ص: 9 .

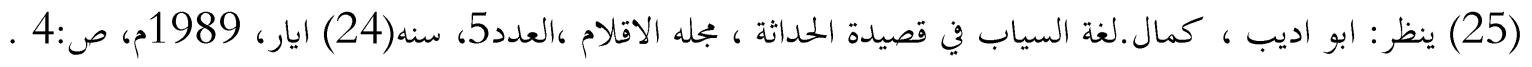

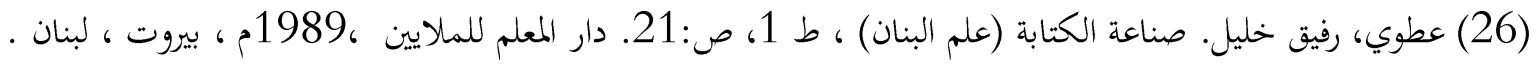

(27) الطرابلسي، محمد الهادي. خصائص الاسلوب في الشوقيات، ص:143 ـ منشورات الجامعة التونسية ،طبع بالمطبعة الرسمية للجمهورية التونسية، 1981م. (28) ينظر: عصفور ، جابر. الصورة الفنية في التراث النقدي والبلاغي عند العرب .ط3، ص:172دار النشر المركز الثقافي العربي،1992م، لبنان،بيروت . 
(29) (29) المصدر نفسه ، ص:172.

(30) الغذامي ، عبدالله محمد ـ المشاكلة والاختلاف، قراءة في النظرية النقدية العربية وبحث في التشبيه المختلفة، ط1، ص:6 ـ ـ الدار

$$
\text { البيضاء، (3) 1994م،بيروت. }
$$

(31) فضل، صلاح .علم الاسلوب مبادئه واجزائه. ط1، ص:259 ـ دار الآداب، 1995م، بيروت، لبنان.

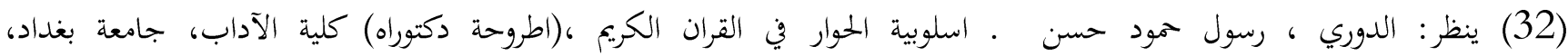

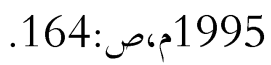

(33) بستاني، صبحي. الصورة الشعرية في الكناية الفنية الاصول والفروع، 113، ص:115 دار الفكر اللبناني،1986م .

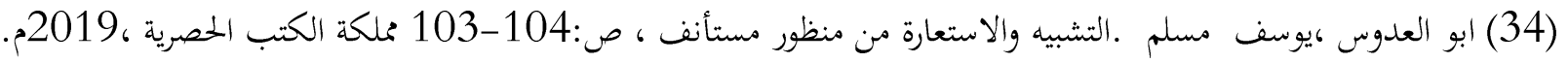

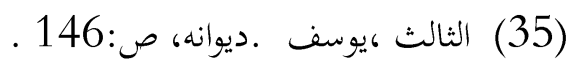

(36) ناجي، جيد عبدالحميد. الاسس النفسية الاساليب البلاغية العربية، ط1، ص:62. المؤسسة الجامعية للدراسات والنشر،1984م،

لبنان.

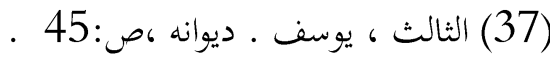

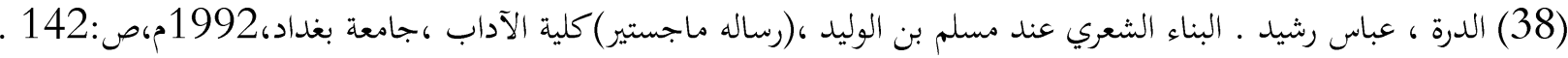

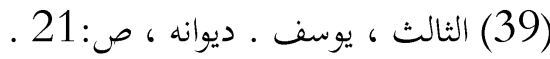

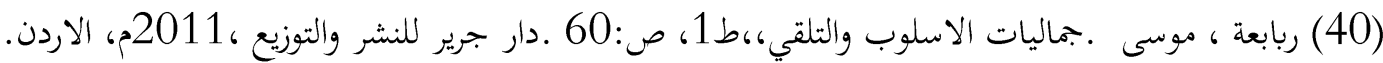

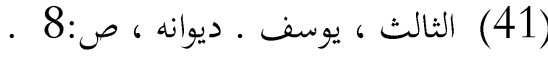

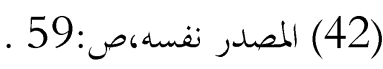

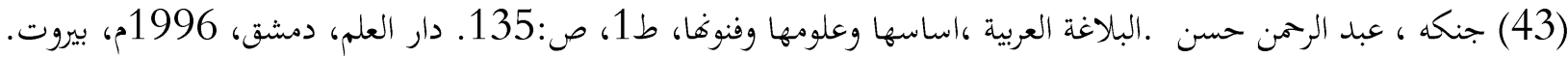

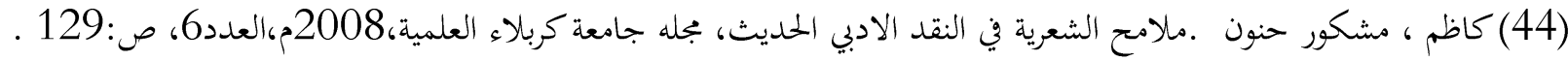

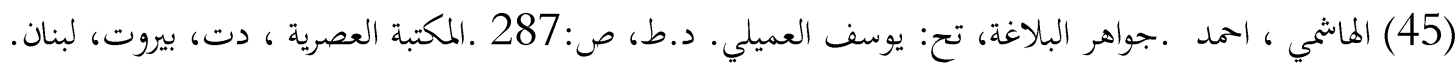

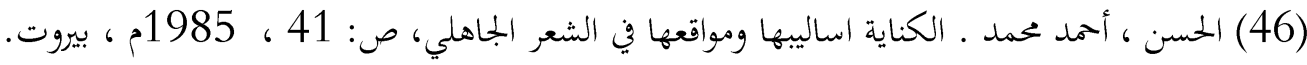

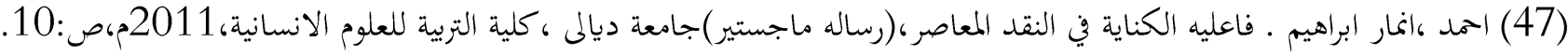

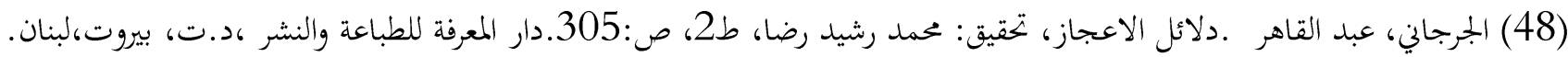

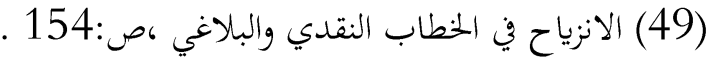

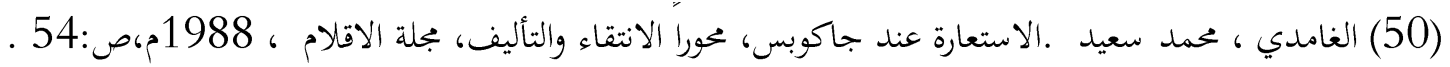

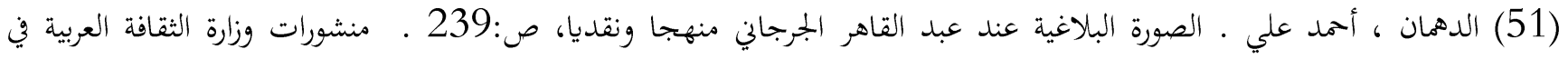

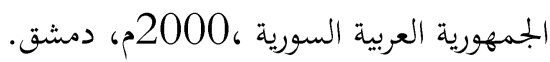

(52) الثالث ، يوسف ـ ديوانه، ص:196 العربية المرية 
(53) ينظر : محمد ، ناظم دعاس عواد ـ جماليات الانزياح في الشعر العربي السري الرفاء أنموذجا ،(رساله ماجستير)جامعة الانبار، كلية

الآداب ،2014م، ص:128 .

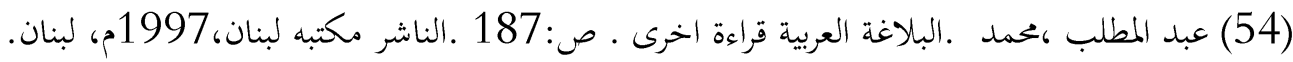

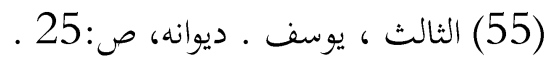

.6 (56) المصدر نفسه،ص:

(57) ينظر : صالح ، عامر مهاي ـ البنى الاسلوبية في تفسير قصار السور من خلال جهود المحدثين،(رساله ماجستير)كلية التربية ،جامعة

الانبار، 1999م:198

(58) الثالث ، يوسف ـ ديوانه، ص:99)

(59) ينظر: فضل ، صلاح . نظرية البنائية في النقد الادبي، ط1، ص:374 ـ الناشر دار الشروق، 1998م، القاهرة.

(60) الثالث ،يوسف ـ ديوانه، ص:40.

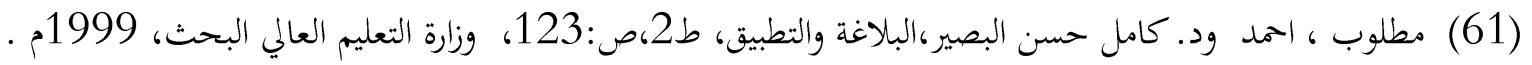

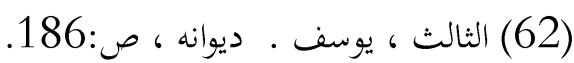

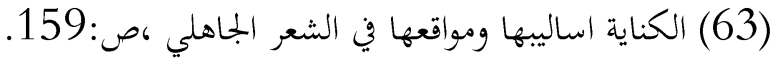

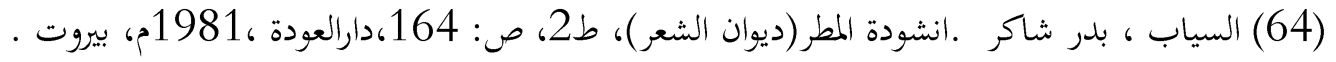

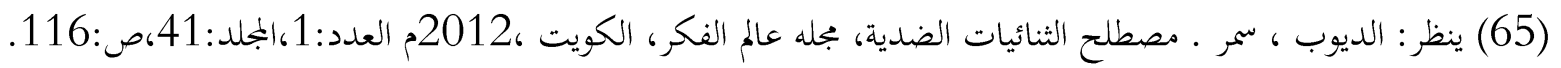

(66) الامين ، محمد ولد عابدين ولد السيد ،الشعر المعاصر في موريتانيا(1980-1998م)، دراسة أسلوبية ،(رساله ماجستير)كلية

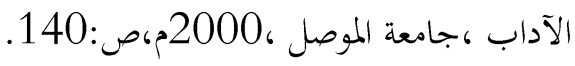

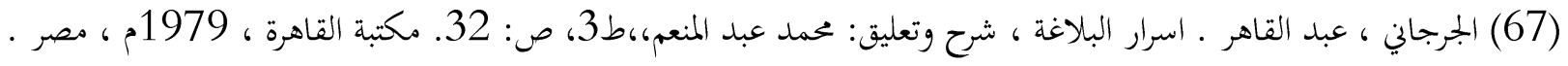

(68) الديوب ، سمر. الثنائيات الضدية ،بحث في المصطلح ودلالاته، ط1، ص:34، المركز الاسلامي للدراسات الاستراتيجية، 2017م .

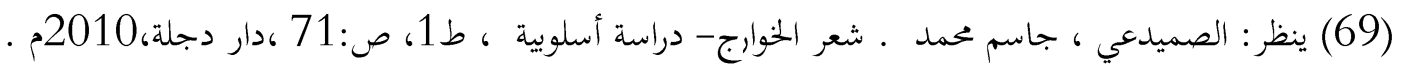

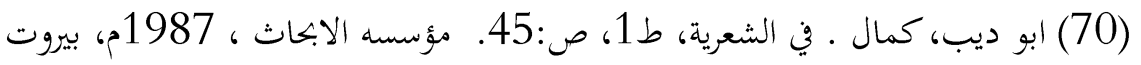

(71) (المصدر نفسه،ص:(71)

(72) الثالث ، يوسف ـ ديوانه ،ص:34.

(73)

(74) ينظر: شاكر، محمد وصبا عاصم. التضاد والعلاقات الثنائية في شعر المعاقين، مجله بابل للدراسات الانسانية, العدد1، الجملد6،

(75) نجا، اشرف محمد. قصيدة المديح في الاندلس، قضايا الموضوعية والفنية (عصر الطوائف)، ط3،ص:325. الدار الوفاء لدينا الطباعة والنشر ، 2003.

(76) مصطلح الثنائيات الضدية،ص:119.

(77) الثالث ، يوسف ـ ديوانه،ص:68. 
(78) ينظر: درابسة ، محمود ـ ظواهر اسلوبية في كتاب جوهر الكنز لابن أثير الملبي ،بجله ابحاث اليرموك، جامعة اليرموك، الاردن،1999م

$$
\text { ، العدد1 ،ص:191. }
$$

(79) الثالث ، يوسف ـ ديوانه ،ص:14.

(80) قبيلات ، نزار وعلي الشروش .الثنائيات، دراسة في شعر محمود درويش، بحله دراسات، العلوم الانسانية والاجتماعية،2011م

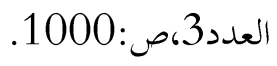

(81) الثالث ، يوسف ـ ديوانه،ص:195.

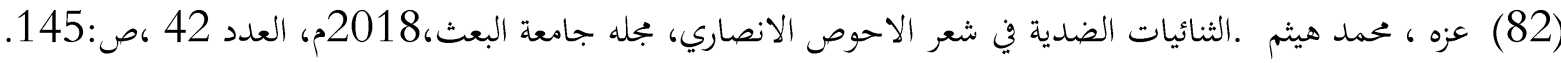

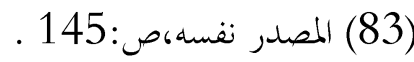

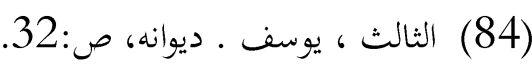

(85) صولة ،عبدالله .فكرة العدول في البحوث الاسلوبية المعاصرة .بجله دراسات سيمائية ادبية لعلوم الانسانية، 1987م، العدد1،،ص:99. 